\title{
W OKRESIE POWOLNEJ MODERNIZACJI. KOBIETA W II RZECZYPOSPOLITEJ - PRÓBA BILANSU
}

\section{Joanna Dufrat}

D http://orcid.org/0000-0003-4143-0026

Uniwersytet Wrocławski

\section{ABSTRACT \\ IN THE PERIOD OF SLOW MODERNIZATION: WOMEN IN THE SECOND REPUBLIC OF POLAND - CONCLUSIONS}

The First World War was an important factor in social modernization, bringing a new order of gender in public space. Among the most important changes in the situation of women in the post-war period, historians mention: obtaining full citizenship rights and broad access to education, increasing professional and educational aspirations, the evolution of intra-family relationships, increasing the proportion of active women, loosening of moral norms and a revolution in women's fashion. Nevertheless, in the Second Republic, there was a visible widening of women's life opportunities and increase of their independence in many areas of social life and in the public sphere. The granting of passive and active electoral law became the symbol of changes that took place in the social position of women after Poland regained its independence in November 1918.

The aim of this article is to discuss the most important aspects of women's participation in the political and social life of the Second Republic (1918-1939), as well as to follow social modernization processes in the context of women's situation: labor market opportunities, educational aspirations, political activity, and changes in family and fashion. Another goal is the analysis of social structures that had the most powerful impact on women's lives: tradition, economics, law.

Keywords: the First Word War, the Second Republic of Poland, modernization, situation of women, stereotypes, women's education, equality at home, women in politics.

Słowa kluczowe: I wojna światowa, II Rzeczpospolita, modernizacja, sytuacja kobiet, aktywność polityczna i społeczna kobiet, aktywność zawodowa kobiet, stereotypy, edukacja kobiet, przemiany obyczajowe.

Okres międzywojenny stanowił kontynuację procesów modernizacyjnych zapoczątkowanych w Europie w XIX stuleciu i przyśpieszonych przez wybuch I wojny światowej. W sferze społecznej procesy te przejawiały się między innymi w postępującej urbanizacji, upowszechnieniu oświaty, wzroście poziomu aspiracji życiowych 
i indywidualnej podatności na zmianę oraz sekularyzacji norm i wartości. Równie istotne były towarzyszące tym zjawiskom przemiany w obyczajowości i społecznym statusie kobiet. Modernizacja społeczeństw europejskich dokonywała się równolegle z procesem demokratyzacji, poszerzania zakresu swobód i równości politycznej'

Odradzająca się po latach niewoli II Rzeczpospolita zarówno pod względem urbanizacji i uprzemysłowienia, jak i nowoczesnej gospodarki rolnej pozostawała w tyle za najbardziej cywilizacyjnie rozwiniętymi społeczeństwami Europy. Wyróżniała się wysokim bezrobociem w miastach, przeludnieniem wsi i jednym $\mathrm{z}$ najwyższych na Starym Kontynencie przyrostem naturalnym. Chociaż w dwudziestoleciu międzywojennym dokonał się w Polsce mały wzrost liczby ludności miejskiej, z 24\% do 30\%, a wraz z rozwojem nowych gałęzi przemysłu zwiększyła się liczba robotników przemysłowych, polskie społeczeństwo zachowało swój agrarny charakter. W 1921 roku z rolnictwa żyło $64 \%$ ludności, a w latach $1931-1938$ - 60\%, podczas gdy w bardziej rozwiniętych gospodarczo krajach europejskich odsetek osób utrzymujących się z rolnictwa kształtował się na poziomie poniżej $40 \%$, na przykład w Czechosłowacji $35 \%$, w Niemczech $34,8 \%$, we Francji $26,2 \%{ }^{2}$.

W porównaniu z państwami zachodniej Europy Polskę cechował wysoki odsetek analfabetów, który u progu niepodległości wśród osób w wieku powyżej 10 lat wynosił ponad 33\% ogółu ludności. Wszędzie też odsetek analfabetów wśród kobiet (36\%) był większy niż wśród mężczyzn (30\%). Na początku lat 30. dzięki zaangażowaniu państwa poziom analfabetyzmu zdołano obniżyć do 23\%, ale Polska nadal plasowała się daleko za takimi krajami, jak Francja (6,0\%), Belgia (5,6\%), Czechosłowacja $(4,1 \%)^{3}$. Wszystkie te czynniki powodowały, że zasięg procesów modernizacyjnych na ziemiach polskich miał ograniczony charakter.

Niemniej jednak także w II RP doszło do widocznego poszerzenia życiowych możliwości kobiet i zwiększenia ich samodzielności w wielu obszarach życia społecznego oraz w sferze publicznej. Symbolem zmian, jakie po odzyskaniu przez Polskę niepodległości w listopadzie 1918 roku dokonały się w społecznej pozycji kobiet, stało się przyznanie im biernego i czynnego prawa wyborczego. Tym samym II Rzeczpospolita znalazła się w awangardzie państw europejskich, które podczas wojny lub tuż po jej zakończeniu zrównały bez żadnych ograniczeń polityczne prawa mężczyzn i kobiet, obok takich państw, jak Dania i Islandia (1915), rewolucyjna Rosja, Holandia (czynne prawo wyborcze w 1917 r., bierne - w 1919 r.), Niemcy oraz Wielka Brytania, gdzie jednak do 1928 r. wyborczynie obowiązywał cenzus wieku (ukończone 30 lat). W kolejnych latach międzywojnia pełnię praw wyborczych otrzymały jeszcze mieszkanki: Luksemburga (1919), Szwecji (1919),

${ }^{1}$ Zob. M.S. S z c z e p a ń s k i, Modernizacja [w:] Encyklopedia socjologii, t. 2, Warszawa 1999, s. 268-274; Z. K r a s n o d ę b s k i, Postęp [w:] Stownik spoleczny, red. B. S z 1 a c h t a, Kraków 2004, s. 931.

2 J. T o m a s z e w s k i, Z. L a n d a u, Polska w Europie i świecie 1918-1939, Warszawa 2005, s. $40-41$.

${ }^{3}$ Ibidem, s. 260-261. 
Czechosłowacji (1919), Węgier (1920), całych Stanów Zjednoczonych (1920), Belgii (1921), Portugalii (1931) oraz Hiszpanii (1933)4.

Kierunek ten potwierdziły kolejne akty prawne, łącznie z konstytucją marcową 1921 roku, zakazującą różnicowania praw obywateli ze względu na płeć. W praktyce przez cały okres międzywojenny w II RP utrzymywały się przepisy prawa cywilnego sprzeczne z konstytucyjną zasadą równości płci, które miały swoje źródło w kodeksach państw zaborczych, obowiązujących na terenie państwa polskiego do wybuchu II wojny światowej. W Polsce stosunki osobiste i majątkowe między małżonkami opierały się więc na zasadzie dominującej pozycji mężczyzny: to mąż zarządzał majątkiem żony, decydował w sprawach dotyczących dzieci, do niego należała opieka nad nimi w razie rozwodu lub separacji. Dyskryminacyjny charakter miały także niektóre przepisy uchwalone już po wejściu w życie ustawy konstytucyjnej. Przykładem może być ustawa o państwowej służbie cywilnej z 1922 roku, według której przy przyjmowaniu do służby państwowej organy powinny przestrzegać obowiązującego prawa cywilnego. Jego przepisy uzależniały natomiast podjęcie pracy przez mężatki od zgody męża ${ }^{5}$. Do rangi symbolu dyskryminującego ustawodawstwa urosła tak zwana ustawa celibatowa, wprowadzona przez autonomiczny Sejm Śląski w 1926 roku i obowiązująca na terenie całego województwa śląskiego do 1938 roku, która nakazywała rozwiązanie umowy o pracę z nauczycielką z chwilą zawarcia przez nią związku małżeńskiego ${ }^{6}$. I jakkolwiek ustawodawstwo celibatowe na ziemiach polskich było zjawiskiem wyjątkowym, wprowadzonym wyłącznie na Śląsku, nie ulega wątpliwości, że obowiązujące w międzywojennej Polsce przepisy prawne w wielu wypadkach utrudniały kobietom decydowanie o własnym losie.

Drogą do awansu społecznego i zwiększenia osobistej wolności było wykształcenie. W II RP nowe możliwości w tym zakresie stworzył kobietom system edukacyjny, oparty na powszechnym, bezpłatnym i obowiązkowym nauczaniu na poziomie podstawowym. Jego częścią była również unowocześniona szkoła średnia ogólnokształcąca męska i żeńska o jednakowym programie i poziomie wykładów. W ten sposób po raz pierwszy w dziejach polskiej oświaty średnia szkoła żeńska została oficjalne równouprawniona ${ }^{7}$. Problem polegał na tym, że chociaż formalnie w międzywojennej Polsce przedstawicielki płci żeńskiej miały dostęp do wszystkich szkół na wszystkich poziomach nauczania, to w praktyce ich możliwości zdobycia wykształcenia były mocno ograniczone. Przede wszystkim działała tradycja. O ile $\mathrm{w}$ dużych miastach w środowisku inteligencko-mieszczańskim nikt nie kwestionował

${ }^{4}$ Zob. R.J. E v a n s, The Feminists: Women's Emancipation Movements In Europe, America, and Australasia, 1840-1920, London 2014, oraz zbiór artykułów w: Women's Emancipation Movements in the 19 $9^{\text {th }}$ Century: A European Perspective, ed. S. Palets check, B. Pietrow-En nker, Stanford 2004.

${ }_{5}$ Zob. więcej: M. P i e $t \mathrm{r}$ z a k, Sytuacja prawna kobiet w Drugiej Rzeczypospolitej [w:] Równe prawa i nierówne szanse. Kobiety w Polsce międzywojennej, red. A. Ż a r n o w s k a i A. S z w a r c, Warszawa 2000, s. 77-90.

6 „Dziennik Ustaw Śląskich” z 1926, nr 8, poz. 12. Na mocy decyzji Prezydenta RP z 1933 r. postanowienia ustawy celibatowej zostały włączone do ustawy o stosunkach służbowych nauczycieli z VII $1926 \mathrm{r}$.

7 J. M i ą s o, Kształcenie dziewczat w Drugiej Rzeczypospolitej [w:] Kobieta i edukacja na ziemiach polskich $w X I X i X X$ w. red. A. Ż a r n o w s k a, A. S z w a r c, t. 2, cz. 2, Warszawa 1992, s. 49-50. 
już potrzeby kształcenia dziewcząt, o tyle na wsi i w małych miasteczkach nadal panowało przekonanie, że wystarczy im umiejętność czytania i pisania, ponieważ w życiu kobiet edukacja odgrywa mniejszą rolę niż w życiu mężczyzn. Poza tym dziewczęta na wsi częściej niż chłopcy przerywały naukę ze względu na obowiązki w gospodarstwie domowym. Dodatkowym czynnikiem ograniczającym dziewczętom zdobycie wykształcenia ponadpodstawowego była mała liczba państwowych szkół koedukacyjnych. W wielu ośrodkach miejskich funkcjonowały wyłącznie szkoły prywatne, stanowiące zdecydowaną większość szkolnictwa średniego, co zmuszało rodziców do pokrywania wysokich kosztów nauki, a nie każdego było na to stać. W konsekwencji według danych statystycznych dziewczęta stanowiły około $41 \%$ ogółu maturzystów. Przy czym tylko niecałe 7\% maturzystek kończyło studia wyższe. Niemniej jednak to, że kobiety stanowiły w II RP od 25\% do 30\% ogółu studentów, było znacznym postępem w porównaniu z okresem przedwojennym.

Swój wymiar praktyczny, obok formalnoprawnego, miało również równouprawnienie polityczne kobiet. W II RP ich udział w tej sferze życia publicznego był więcej niż skromny. Pomimo dużej aktywności wyborczej, która nie odbiegała od średniej ogólnokrajowej, kobiety rzadziej korzystały z biernego prawa wyborczego. Na przykład w wyborach 1922 roku w całym kraju wśród 5189 osób kandydujących do Sejmu kobiet było 113, a wśród 998 osób ubiegających się o mandat senatora - 17. Z kolei w wyborach 1935 roku, które odbywały się na podstawie nowej, antydemokratycznej ordynacji wyborczej i w warunkach bojkotu partii opozycji antysanacyjnej, w 104 okręgach wyborczych wśród 416 kandydatów do zredukowanego liczebnie parlamentu było zaledwie 14 kobiet, spośród których tylko jedna startowała z drugiego miejsca ${ }^{8}$. Analiza lokat zajmowanych przez kandydatki na listach wyborczych również świadczy o nierówności płci w dostępie do podziału mandatów. Przytłaczająca większość kandydatur kobiecych była umieszczana na miejscach niedających szans na odniesienie wyborczego sukcesu?

Zainteresowanie partii politycznych żeńskim elektoratem ujawniało się głównie podczas krótkich okresów kampanii wyborczych. Po tym czasie liderzy partyjni lekceważyli obecność kobiet w życiu politycznym. Nie dopuszczali do eksponowanych stanowisk, jednocześnie z niechęcią odnosili się do podejmowanych przez nie prób osiągnięcia politycznej samodzielności. W rezultacie w dwudziestoleciu międzywojennym kobiety nie współkształtowały obozów ideowo-politycznych, w ramach których funkcjonowały, a ich aktywność w tych ugrupowaniach nie była zauważalna dla opinii publicznej ${ }^{10}$.

Niewiele przedstawicielek płci żeńskiej zasiadało w organach ustawodawczych państwa. Piastowały one łącznie 68 mandatów (46 poselskich i 22 senatorskie),

${ }^{8}$ L. Hass, Aktywność wyborcza kobiet w pierwszym dziesięcioleciu Drugiej Rzeczypospolitej [w:] Kobiety $i$ świat polityki w niepodległej Polsce 1918-1939, red. A. Ża rnow s ka, A. S zw arc, Warszawa 1996, s. 82-89, 92.

${ }^{9}$ Więcej: M. K o n d r a c k a, Postanki i senatorki II Rzeczypospolitej, Warszawa 2017, s. 76-79.

${ }^{10}$ Zob.: J. D u f r a t, Narodowa Organizacja Kobiet i Zwiazek Pracy Obywatelskiej Kobiet podobieństwa i różnice. Kilka uwag o funkcjonowaniu spoleczno-politycznych organizacji kobiecych w Drugiej Rzeczypospolitej [w:] Polska leży na Zachodzie. Studia z dziejów Polski i Europy dedykowane Pani Profesor Teresie Kulak, red. W. Wrzes ińs ki, M. Masn y k, K. Kaw a le c, Toruń 2011, s. 574-584. 
podczas gdy wszystkich parlamentarzystów w okresie międzywojennym było około 2500. W parlamencie II RP kobiety stanowiły więc w przybliżeniu $2,5 \%$ całej grupy posłów i senatorów. Najwyższy odsetek parlamentarzystek - 22 (4\% ogółu) zasiadał w Sejmie i Senacie III kadencji (1930-1935). Należy też podkreślić, że w porównaniu z innymi krajami europejskimi, które wprowadziły po I wojnie światowej powszechne prawa wyborcze, w Polsce wskaźnik reprezentacji kobiet w parlamentarnych organach przedstawicielskich był niższy ${ }^{11}$.

Jednocześnie z niewielką liczbą kobiet piastujących mandaty parlamentarne kontrastowało zaskakująco nowoczesne ustawodawstwo pracy i opieki społecznej obowiązujące w Polsce, która wyprzedziła pod tym względem lepiej rozwinięte kraje europejskie. Dzięki wysiłkom parlamentarzystek Sejm uchwalił w latach 20. między innymi ustawę o ograniczeniu punktów sprzedaży napojów alkoholowych (1920), ustawę znoszącą prawnocywilne ograniczenia praw kobiet (1921), ustawę o opiece społecznej (1923) oraz o pracy chronionej (1924), która wprowadzała urlopy macierzyńskie i zakazywała wykonywania przez kobiety i młodzież prac w warunkach szkodliwych dla zdrowia ${ }^{12}$. Z projektów popieranych przez środowiska kobiece nie udało się natomiast uchwalić ustawy o służbie domowej, ustawy polepszającej sytuację prawną dzieci nieślubnych oraz przyznającej żonom prawo swobodnego wyboru obywatelstwa w wypadku małżeństwa z cudzoziemcem lub zmiany obywatelstwa przez męża. Także postępowy projekt prawa małżeńskiego, który przewidywał fakultatywne śluby cywilne i wyznaniowe, rozwody cywilne oraz prawną równość małżonków, opracowany w 1929 roku przez Komisję Kodyfikacyjną, nie stał się obowiązującym prawem ze względu na sprzeciw Kościoła katolickiego ${ }^{13}$.

Atmosfera wokół praw kobiet pogorszyła się w latach 30. wraz z wybuchem kryzysu ekonomicznego. Zbiegł się on w czasie z ewolucją państwa w kierunku autorytarnym oraz pojawieniem się nowych idei, odrzucających zasady demokracji liberalnej i indywidualizmu. W Polsce przedstawiciele obozu rządzącego oficjalnie nie kwestionowali praw obywatelskich kobiet, jednak dla wielu działaczek stawało się jasne, że nie były one też oczywistością. Potwierdzeniem ich obaw okazał się projekt nowej, antydemokratycznej ordynacji wyborczej do Sejmu i Senatu, ujawniony opinii publicznej przez premiera Walerego Sławka w 1935 roku, który w pierwotnej wersji pozbawiał kobiety możliwości brania czynnego udziału w życiu politycznym. Przewidywał bowiem, że kandydatów będą wyłaniały zgromadzenia okręgowe, złożone z przedstawicieli samorządu terytorialnego, gospodarczego i zawodowego oraz zrzeszeń zawodowych, do których kobiety nie należały lub - stanowiąc w nich znikomy procent - nie mogły liczyć na poparcie mężczyzn. Nacisk zorganizowanych środowisk kobiecych spowodował przyjęcie korekty, która w największych okręgach wyborczych przewidywała możliwość wejścia do zgromadzeń wyborczych maksymalnie pięciu delegatek stowarzyszeń kobiecych. Jednak w niewielkim stopniu poprawiło to sytuację kobiet, które stanowiły mniej niż 10\% delegatów okręgowych,

${ }^{11}$ M. K o n d r a c k a, op. cit., s. 83-86.

${ }_{12}$ M. Ś 1 i w a, Udziat kobiet $w$ wyborach $i$ ich działalność parlamentarna [w:] Równe prawa i nierówne szanse, s. 53.

${ }^{13}$ M. P i e tr z a k, op. cit., s. 83-85. 
nie miały zatem możliwości przeforsowywania swoich kandydatek na listy wybor$\mathrm{cze}^{14}$. W ostatnich wyborach parlamentarnych, które odbyły się w 1938 roku, kobiety uzyskały zaledwie jeden mandat poselski i cztery senatorskie ( $w$ tym dwa z nominacji prezydenta RP), najmniej w międzywojennej Polsce ${ }^{15}$.

Historycy podkreślają polityczną bierność mas kobiecych w dwudziestoleciu międzywojennym, chociaż - jak słusznie zauważył Andrzej Chojnowski - w czasach II RP stanowiła ona problem ogólniejszej natury ${ }^{16}$. Społeczeństwo polskie żyło W większości rytmem tradycjonalistycznego społeczeństwa agrarnego, skoncentrowanego na własnych problemach materialnych i słabo zainteresowanego sprawami ogólnopaństwowymi. Faktem jest, że zdecydowana większość mieszkanek Polski nie uczestniczyła w kampaniach wyborczych ani nie interesowała się sprawami wyborów. Zjawisko to w większym stopniu występowało na terenach wiejskich, w mniejszym w dużych miastach, skupiających większą liczbę kobiet wykształconych i aktywnych zawodowo. Poza obyczajowym konserwatyzmem, przeciążeniem domowymi obowiązkami i brakiem wolnego czasu wpływ na tę sytuację wywierała niska kultura polityczna kobiet, które często nie rozumiały związku między życiem codziennym a konkretnymi rozstrzygnięciami w sferze politycznej.

Czynnikiem hamującym podejmowanie przez kobiety działalności stricte politycznej był także silny nacisk tradycji jednoznacznie zawężającej zainteresowania kobiet do spraw domu i rodziny i wskazującej, że przestrzeń publiczna, związana ze sprawowaniem władzy, jest zarezerwowana dla mężczyzn. Potwierdzenie tej zasady mogły one znaleźć w znanej im rzeczywistości, w której mężczyźni pełnili funkcje kierownicze, natomiast kobiety z reguły zajmowały podporządkowane im stanowiska. Dlatego też polityka, jako sfera związana z władzą i decyzyjnością, jawiła się zarówno kobietom, jak i niechętnej (męskiej) opinii publicznej jako „niekobieca"17. Co zaskakujące, wbrew swoim intencjom stereotyp ten utrwalały publicystki i liderki organizacji zainteresowanych zwiększeniem udziału mas kobiecych w życiu publicznym. Ich przekaz kierowany do kobiet był pełen sprzeczności: z jednej strony wzywały je do zainteresowania się sprawami publicznymi i aktywności w szeroko rozumianym życiu politycznym, $\mathrm{z}$ drugiej - w żaden sposób nie próbowały podważyć tradycyjnych wyobrażeń o ich społecznej roli.

Uwikłanie elit kobiecych w tradycyjne myślenie o roli kobiet dobrze ilustruje też międzywojenny dyskurs na temat modelu polskiej obywatelki, w którym nieustannie podkreślano służebną rolę kobiet w społeczeństwie i przekonywano, że wraz z otrzymaniem praw obywatelskich ich funkcje pełnione dotąd w rodzinie nie tyle ulegną modyfikacji, co zostaną rozszerzone na sferę publiczną państwa. Potwierdzał również tę zasadę deklarowany zakres problemów, którymi Polki miały zajmować się

${ }^{14}$ Szerzej zob.: J. D u f r a t, $W$ stużbie obozu marszałka Józefa Piłsudskiego. Związek Pracy Obywatelskiej Kobiet (1928-1939), Kraków 2013, s. 338-342.

${ }^{15}$ Ibidem, s. 346-347, 388-395.

${ }^{16}$ A. C h o j n o w s k i, Aktywność kobiet w życiu politycznym [w:] Równe prawa i nierówne szanse, s. 37; M. Ś 1 i w a, Udziat kobiet w wyborach $i$ ich działalność parlamentarna, s. 50.

17 J. D u f r a t, W stużbie obozu marszałka Józefa Pitsudskiego. Związek Pracy Obywatelskiej Kobiet (1928-1939), s. 141. 
w życiu publicznym. Należały do nich kwestie uchodzące w powszechnym odczuciu za „typowo kobiece”, tj. wspieranie potrzebujących, wychowanie dzieci, troska o zdrowie i rodzinę. Wszystko to świadczyło o świadomości istnienia granicy między tym, co jeszcze jest „kobiece”, a co jest wchodzeniem w role męskie. I respektowaniu tego podziału ${ }^{18}$. Powyższa retoryka sprzyjała utrzymywaniu uprzedzeń wynikających z panujących stereotypów i mogła utwierdzać opinię publiczną w przekonaniu o braku kompetencji przedstawicielek płci żeńskiej do zajmowania się polityką. Dotyczyło to również poglądów samych kobiet. Wyraźniejsze symptomy przełomu w politycznym zaangażowaniu przedstawicielek płci żeńskiej wystąpiły dopiero w młodszych pokoleniach wkraczających w dorosłe życie w połowie lat 30., które aktywizowały się przede wszystkim w ruchu nacjonalistycznym i ludowym. Niestety, problem aktywności kobiet w świecie polityki, przyczyn ich większej lub mniejszej obecności w obrębie poszczególnych nurtów politycznych II Rzeczypospolitej czy relacji płci w strukturach partyjnych, mimo znacznego poszerzenia pola badawczego w ostatnich latach, wciąż jest mało znany i nie pozwala na sformułowanie szerszych wniosków, a tym bardziej dokonanie porównań z sytuacją kobiet w innych krajach.

W kontekście społecznej modernizacji istotniejsze następstwa dla emancypacji kobiet w warstwie obyczajowej i mentalnej przyniósł rozwój ich aktywności zawodowej i zarobkowej. Jego tempo w dużej mierze uzależnione było jednak od tempa procesów unowocześniania i uprzemysłowienia ziem polskich, te zaś przebiegały bardzo powoli. W przełożeniu na sytuację populacji żeńskiej oznaczało to, że w międzywojennej Polsce nadal blisko $70 \%$ przedstawicielek płci żeńskiej mieszkało na wsi. Jednak to kobiety częściej od mężczyzn wyruszały ze wsi do miast.

W II RP mamy do czynienia z wyraźnym wzrostem liczby kobiet podejmujących pracę poza rolnictwem przy jednoczesnym rozszerzaniu się zjawiska pracy zawodowej kobiet. Z danych przytoczonych przez J. Żarnowskiego wynika, że między 1921 a 1931 rokiem liczba kobiet czynnych zawodowo wzrosła o prawie $60 \%$, podczas gdy ogólna liczba pracujących poza rolnictwem tylko o około $46 \%$. Wskazywałoby to na szybszą dynamikę zmian w grupie żeńskiej w porównaniu z analogicznymi przesunięciami $\mathrm{w}$ grupie męskiej. $\mathrm{W}$ tym samym okresie udział kobiet $\mathrm{w}$ populacji zawodowo czynnych wzrósł z 29,13\% do 31,37\%. W liczbach bezwzględnych najbardziej, bo przeszło dwukrotnie zwiększyła się liczba pracujących w przemyśle, gdzie mechanizacja stworzyła warunki do zatrudnienia niewykwalifikowanej siły roboczej. Podwoiła się także liczba pracujących w handlu i w służbie publicz$n^{19}{ }^{19}$. W Polsce, analogicznie do sytuacji w innych krajach europejskich, następował też proces przesuwania się kobiet do zawodów, które przed wojną uważane były za zajęcia typowo męskie. Stopniowej feminizacji uległa praca w usługach, biurach i urzędach oraz w niektórych gałęziach przemysłu (metalurgiczny, chemiczny, poligraficzny). Wskazywało to na powolne unowocześnianie się składu zawodowego kobiecej zbiorowości, chociaż bardzo wysoka liczba służby domowej świadczyła

${ }^{18}$ D. D ą b r o w s k a, Udomowiony świat. O kobiecym doświadczaniu historii, Szczecin 2004, s. $151,174$.

19 J. Ż a r n o w s k i, Praca zawodowa kobiet w Polsce międzywojennej [w:] Kobieta i praca. Wiek $X I X i X X$, t. 6, red. A. Żarnows ka, A. Szwarc, Warszawa 2000, s. 121-122. 
równocześnie o ciągłym utrzymywaniu się w Polsce archaicznego układu stosunków w zakresie pracy zawodowej kobiet ${ }^{20}$.

W II RP największe zmiany w aktywności zawodowej objęły przedstawicielki warstw inteligencko-mieszczańskich, posiadające średnie i wyższe wykształcenie. Znajdowały one pracę $\mathrm{w}$ wolnych zawodach bądź zatrudniały się $\mathrm{w}$ charakterze pracownic biurowych w nowo tworzonych instytucjach życia publicznego oraz w szkolnictwie. Zwiększenie się udziału kobiet wśród pracowników umysłowych w Polsce odnotowały powszechne spisy ludności: w 1921 roku odsetek ten wynosił 27,54, a w 1931 roku już 29,8721. Dominowały wśród nich - podobnie jak w środowisku robotniczym - kobiety młode i niezamężne. $Z$ reguły też większość z nich rezygnowała z pracy po zamążpójściu. Mężatki stanowiły niecałe $30 \%$ zatrudnionych $^{22}$. O ile jednak w niższych warstwach społecznych praca zawodowa kobiet w zdecydowanej większości wymuszona była złą sytuacją ekonomiczną, o tyle przedstawicielki inteligencji coraz częściej postrzegały ją jako przejaw nowoczesności. W tym środowisku o jej podjęciu decydowały również czynniki pozaekonomiczne, związane z dążeniem do materialnej niezależności i chęcią samorealizacji23.

Pracujące kobiety zetknęly się z problemem dyskryminacji, przejawiającym się między innymi w niższych płacach za tę samą pracę oraz - w przypadku inteligentek - również w utrudnieniach przy awansach. Należy ponadto pamiętać o utrzymujących się barierach w dostępie do niektórych zawodów. Do 1929 roku kobiety nie mogły na przykład pełnić funkcji sędziowskich. Od 1919 roku mogły natomiast odbywać aplikację sądową jako przygotowanie do zawodu adwokackiego. Ówczesne otwarcie dostępu do zawodu adwokata sprawiło, że w 1933 roku w II RP pracowało już 101 adwokatek, a do wybuchu wojny liczba ta mogła wzrosnąć do około 200. Natomiast do końca okresu międzywojennego stanowisko sędziego objęło zaledwie osiem kobiet ${ }^{24}$.

Pomimo presji tradycyjnych wzorców, łączących aktywność kobiet głównie z gospodarstwem domowym i rodziną, w dwudziestoleciu międzywojennym praca zarobkowa kobiet poza domem stała się na tyle powszechna i obecna w społecznej świadomości, że w zasadzie została zaakceptowana przez opinię publiczną i przestała budzić emocje, przynajmniej w odniesieniu do kobiet nieposiadających rodziny

${ }^{20}$ A. Ż a r n o w s k a, Kierunki aktywności zawodowej kobiet w Polsce w XX wieku (do 1939 r.) [w:] Kobieta i edukacja na ziemiach polskich $w$ XIX $i$ XX w., red. A. Żarnowska, A. Szwarc, t. 2, cz. 2, Warszawa 1998, s. 115-116; eadem, Obywatelki II Rzeczypospolitej [w:] Równe prawa i nierówne szanse, s. 293; W. M i e r z e c k i, Praca zarobkowa kobiet w środowisku robotniczym w Polsce międzywojennej [w:] Równe prawa i nierówne szanse, s. 111.

${ }^{21} \mathrm{~J} . \dot{Z}$ a $\mathrm{r} \mathrm{n}$ o w s k i, Praca zawodowa kobiet $w$ Polsce międzywojennej, s. 128. Zob. też: A. Żarnow ska, Kierunki aktywności zawodowej kobiet w Polsce $w$ XX wieku (do 1939 r.), s. 113-121.

22 J. Żarnowski, Praca zawodowa kobiet w Polsce międzywojennej, s. 129; W. M i e r z e c k i, Praca zarobkowa kobiet w środowisku robotniczym w Polsce międzywojennej, s. 111.

${ }^{23} \mathrm{~K} . \mathrm{S}$ i e $\mathrm{r}$ a k o w s k a, Aspiracje zawodowe kobiety zamężnej $w$ rodzinach inteligenckich lat międzywojennych $w$ opinii prasy kobiecej i poradników dla kobiet [w:] Kobieta i praca. Wiek XIX i XX, s. 296.

${ }^{24}$ L. K r z y ż a n o w s k i, W. O k n i ń s k i, Temida wyemancypowana? Stownik biograficzny kobiet - sędziów, asesorów i egzaminowanych aplikantów w międzywojennym sądownictwie polskim, Sopot 2018, s. 11-24. 
i pracę podejmujących z pobudek ekonomicznych. Jednocześnie w II RP płatnej pracy kobiet nie traktowano jako „wartości dodanej” i - niezależnie od wykonywanego zawodu - nadawano jej niższą rangę od pracy mężczyzn ${ }^{25}$.

Niejednoznaczny stosunek opinii publicznej do kobiecej aktywności zawodowej z dużą siłą ujawnił się na początku lat 30 . w okresie kryzysu gospodarczego i w dobie narastania tendencji autorytarnych, gdy powszechnie zaczęto kwestionować prawo kobiet do pracy zarobkowej, prawo, jak się wcześniej zdawało, utrwalone i powszechnie zaakceptowane. Było to tym groźniejsze dla idei równouprawnienia, że rolę czynnika broniącego $\mathrm{w}$ ten sposób tradycyjnych wartości przyjęły na siebie instytucje państwowe, które pod pretekstem „ratowania ogniska domowego" i walki z bezrobociem rozpoczęły nieformalną akcję zwalniania mężatek z urzędów państwowych. Spowodowało to znaczne ograniczenie liczby kobiet czynnych zawodowo, zwłaszcza w służbie publicznej. Poza tym w 1935 roku po raz pierwszy w dwudziestoleciu międzywojennym pojawił się w Sejmie pomysł ustawowego ograniczenia możliwości zajmowania posad przez męża i żonę, przedstawiony przez wicepremiera i ministra gospodarki Eugeniusza Kwiatkowskiego, z którego rząd wycofał się w $1936 \mathrm{roku}^{26}$.

Z pracą zarobkową i zawodową kobiet ściśle łączyły się przemiany w obyczajowości, które w miarę powszechnie zaznaczyły się głównie w większych miastach. Najbardziej widocznym przejawem dokonujących się ówcześnie przeobrażeń społeczno-gospodarczych i obyczajowych była rewolucja w kobiecym wyglądzie. Pojawiły się ubiory proste, praktyczne, ,zracjonalizowane”. Powojenna moda odsłoniła ciało, ułatwiała poruszanie się po domu i ulicy, korzystanie z komunikacji miejskiej i podejmowanie pracy zarobkowej. Była luźniejsza i łatwiejsza do naśladowania. Przenikanie do warstw niższych wzorców lepiej usytuowanych warstw wielkomiejskich wpływało na stopniową standaryzację i zanikanie różnic $\mathrm{w}$ sposobie ubierania się przedstawicielek różnych grup społecznych. W bardziej tradycyjnych społecznościach wiejskich i małomiasteczkowych przyjmowano je jednak z opóźnieniem. $\mathrm{Na}$ wsi strój starszych kobiet nie uległ zasadniczym zmianom ${ }^{27}$.

Skutkujące wzrostem niezależności ekonomicznej uzawodowienie kobiet, a także ich zwiększona aktywność w sferze publicznej sprzyjały również przeobrażeniom relacji wewnątrzrodzinnych, ale zmiany w tym zakresie objęły bardzo niewielką część społeczeństwa. W dwudziestoleciu międzywojennym wzorce nowoczesnej rodziny wytworzyła przede wszystkim wielkomiejska inteligencja. W tej grupie tendencje równościowe w relacjach między mężem i żoną wzmacniane były dodatkowo przez zauważalny wzrost liczby małżeństw rówieśniczych, o niewielkiej różnicy wieku między małżonkami, oraz ograniczenie liczby potomstwa. Celem małżeństwa

${ }_{25}$ M. G a w i n, Gtosy krytyczne w sprawie zawodowej pracy kobiet 1918-1939 (w świetle publicystyki) [w:] Kobieta i praca. Wiek XIX i XX, s. 303-315.

${ }_{26}$ Państwowe Archiwum Obwodu Brzeskiego, f. 390, o.1, d.1, Pismo prezesa Rady Ministrów z 18 III 1936 r. dotyczące interpelacji sen. Jaroszewiczowej w sprawie zarządzenia rządowego o zwalnianiu mężatek ze służby państwowej, k. 136.

${ }_{27}$ Zob. A. S i e r a d z k a, Moda w przedwojennej Polsce, Warszawa 2013, s. 39-50, 56; J. Żarnow ski, Polska 1918-1939. Praca-Technika-Spoleczeństwo, Warszawa 1999, s. 253-258. 
przestało być posiadanie dzieci, a punkt ciężkości w relacjach między mężem i żoną zaczął się przesuwać w kierunku budowania satysfakcji emocjonalnej. W dwudziestoleciu nie doszło jednak do zmiany tradycyjnego podziału obowiązków w rodzinie. Nadal szczególną pozycję zajmował mężczyzna uznawany za głównego żywiciela, kobieta zaś miała być strażniczką domowego ogniska. Efektem zmniejszenia liczby potomstwa $\mathrm{w}$ rodzinie inteligenckiej była natomiast zmiana pozycji dziecka w hierarchii rodzinnych wartości, która sprzyjała integracji rodzinnej wspólnoty ${ }^{28}$.

Tendencja do ograniczania potomstwa zaczęła też z wolna przenikać do szerszych warstw ludności miejskiej oraz do rodzin chłopskich. Jednakże ze względu na niską kulturę seksualną i brak wiedzy o środkach antykoncepcyjnych powszechnym, mimo że nielegalnym i niebezpiecznym, sposobem regulacji urodzeń stała się aborcja. Decydowały się na nią przede wszystkim kobiety zamężne i już posiadające dzieci. W efekcie w międzywojennej Polsce nastąpiło zdecydowane odejście od tak zwanej dzietności naturalnej i wyraźny spadek rodności (z około 40 urodzeń na 1000 mieszkańców w przededniu I wojny światowej do około 25 na 1000 w drugiej połowie lat 30.) ${ }^{29}$.

\section{KONKLUZJE}

Nie ulega wątpliwości, że II RP zapoczątkowała przemiany zmierzające do równouprawnienia kobiet, chociaż korzystanie przez nie z przyznanych praw i wykorzystywanie w pełni nowych możliwości łączyło się z koniecznością nieustannego przekraczania barier i zakazów o charakterze obyczajowym. W kontekście przemian modernizacyjnych i w perspektywie dwudziestolecia widać też wyraźnie, że w tym okresie na sytuację kobiet dużo ważniejszy wpływ od legislacji wywierały uwarunkowania ekonomiczne i społeczno-kulturowe. Dlatego wśród czynników blokujących emancypację kobiet należy wymienić zarówno wzory ról płciowych, funkcjonujące w świadomości społecznej, jak i niski poziom materialny ludności, zapóźnienie cywilizacyjne kraju oraz powolne tempo przemian gospodarczych i związaną z tym słabą dynamikę przekształceń struktury społeczno-zawodowej. Niemniej jednak, mimo tych przeciwieństw, mieszkanki Polski coraz częściej poszerzały granice swojej swobody, a zdobyte wykształcenie otwierało im drogę do awansu społecznego.

Do najważniejszych osiągnięć dwudziestolecia w odniesieniu do sytuacji kobiet należy zaliczyć: uzyskanie pełnych praw obywatelskich i szerokiego dostępu do

${ }^{28}$ Zob. A. Ża rn ow s k a, K. S i e r a k o w s k a, Stare i nowe wzorce i obyczaje rodziny inteligenckiej w Polsce i Europie Środkowo-Wschodniej [w:] Rodzina - prywatność - intymność. Dzieje rodziny polskiej w kontekście europejskim. Sympozjum na XVII Powszechnym Zjeździe Historyków Polskich (Kraków 15-18 września 2004), red. D. Kał wa, A. Wal a s zek, A. Ża rn ow sk a, Warszawa 2006, s. 85-94.

${ }^{29}$ B. O g ó r e k, „Należy przestać spluwać dzieci na prawo i lewo!”. Transformacja płodności w populacji Drugiej Rzeczypospolitej [w:] Społeczeństwo międzywojenne: nowe spojrzenie, red. W. Mędrzecki, J. Żarnowski, Metamorfozy Społeczne, t. 10, Warszawa 2015, s. 103-107; W. Mędrzecki, S. Rudnicki, J. Żarnowski, Społeczeństwo polskie wXX wieku, red. nauk. J. Żarnowski, Warszawa 2003, s. 140. 
edukacji, wzrost aspiracji zawodowych i kształceniowych, ewolucję stosunków wewnątrzrodzinnych, zwiększenie odsetka kobiet czynnych zawodowo, a także rewolucję w kobiecej modzie i rozluźnienie norm obyczajowych. Pozytywnie wyróżnić trzeba także dorobek ustawodawczy państwa. Wzrosła również rola kobiet w kulturze polskiej. Zwłaszcza $\mathrm{w}$ dziedzinie twórczości literackiej ranga pisarek nigdy wcześniej nie była tak wysoka jak w dwudziestoleciu międzywojennym ${ }^{30}$.

Równocześnie należy pamiętać o ograniczonym charakterze wielu $\mathrm{z}$ wymienionych zmian. W międzywojennej Polsce kobietom w zasadzie nie udało się sforsować barier polityki; dziewczęta w większości nadal zajmowały mniej korzystną pozycję od swoich kolegów, a zwiększenie udziału kobiet w życiu publicznym, sprzyjające ich usamodzielnieniu i uzyskaniu przez nie wyższej pozycji społecznej, miało miejsce tylko w nielicznych środowiskach, niemal wyłącznie wielkomiejskich. A osiągnięcie rzeczywistego równouprawnienia wymagało nie tylko przezwyciężenia istniejących stereotypów myślenia i schematów kulturowych. Należało również doprowadzić do sytuacji, w której kobiety w życiu publicznym stałyby się osobami traktowanymi przez opinię publiczną „,bez zbędnej sensacji”31.

\section{BIBLIOGRAFIA}

\section{Archiwalia}

Państwowe Archiwum Obwodu Brzeskiego, f.1 (Urząd Wojewódzki Poleski).

\section{Opracowania}

Chojnowski A., Aktywność kobiet w życiu politycznym [w:] Równe prawa i nierówne szanse. Kobiety w Polsce międzywojennej, red. A. Żarnow s ka, A. S zw ar c, Warszawa 2000.

Dąbrow ska D., Udomowiony świat. O kobiecym doświadczaniu historii, Szczecin 2004.

Dufrat J., Narodowa Organizacja Kobiet i Związek Pracy Obywatelskiej Kobiet - podobieństwa $i$ różnice. Kilka uwag o funkcjonowaniu spoleczno-politycznych organizacji kobiecych w Drugiej Rzeczypospolitej [w:] Polska leży na Zachodzie. Studia z dziejów Polski i Europy dedykowane Pani Profesor Teresie Kulak, red. W. Wrzesiński, M. Masnyk, K. Kaw alec, Toruń 2011.

Dufrat J., W stużbie obozu marszałka Józefa Piłsudskiego. Związek Pracy Obywatelskiej Kobiet (1928-1939), Kraków 2013.

Evans R.J., The Feminists: Women's Emancipation Movements In Europe, America, and Australasia, 1840-1920, London 2014.

${ }^{30}$ H. K i r c h n e r, Pisarki międzywojennego dwudziestolecia [w:] Równe prawa i nierówne szanse, s. 243 .

${ }^{31}$ A. C h o j n o w s k i, Aktywność kobiet w życiu politycznym, s. 42. 
Gaw in M., Głosy krytyczne w sprawie zawodowej pracy kobiet 1918-1939 (w świetle publicystyki) [w:] Kobieta i praca. Wiek XIX i XX, red. A. Żarnowska, A. Szwarc, t. 6, Warszawa 2000.

Has s L., Aktywność wyborcza kobiet w pierwszym dziesięcioleciu Drugiej Rzeczypospolitej, [w:] Kobiety i świat polityki w niepodlegtej Polsce 1918-1939, red. A. Żarnowska, A. Szw arc, Warszawa 1996.

Kirchner H., Pisarki międzywojennego dwudziestolecia [w:] Równe prawa i nierówne szanse. Kobiety w Polsce międzywojennej, red. A. Żarnow sk a, A. S z w a rc, Warszawa 2000.

Kondracka M., Posłanki i senatorki II Rzeczypospolitej, Warszawa 2017.

Kra nodęb ski Z., Postęp [w:] Stownik spoleczny, red. B. S zla ch ta, Kraków 2004.

Krzyżanowski L., Okniński W., Temida wyemancypowana? Stownik biograficzny kobiet - sędziów, asesorów i egzaminowanych aplikantów $w$ międzywojennym sądownictwie polskim, Sopot 2018.

Mędrzecki W., Rudnicki S., Żarnowski J., Społeczeństwo polskie w XX wieku, red. nauk. J. Żarnow ski, Warszawa 2003.

Miąs o J., Kształcenie dziewczat w Drugiej Rzeczypospolitej [w:] Kobieta i edukacja na ziemiach polskich $w X I X i X X$ w. , red. A. Żarnows ka, A. S z warc, t. 2 cz. 2, Warszawa 1992.

Mi erzecki W., Praca zarobkowa kobiet $w$ środowisku robotniczym $w$ Polsce międzywojennej, [w:] Równe prawa i nierówne szanse. Kobiety w Polsce międzywojennej, red. A. Żarnows ka, A. S zw arc, Warszawa 2000.

Ogó rek B., „Należy przestać spluwać dzieci na prawo i lewo!”. Transformacja płodności w populacji Drugiej Rzeczypospolitej [w:] Społeczeństwo międzywojenne: nowe spojrzenie, red. W. Mędr ze cki, J. Żarnow ski, Metamorfozy Społeczne, t. 10, Warszawa 2015.

P ietrzak M., Sytuacja prawna kobiet w Drugiej Rzeczypospolitej [w:] Równe prawa i nierówne szanse. Kobiety $w$ Polsce międzywojennej, red. A. Żarnowska, A. Szwarc, Warszawa 2000.

Sierakowska K., Aspiracje zawodowe kobiety zamężnej w rodzinach inteligenckich lat międzywojennych $w$ opinii prasy kobiecej i poradników dla kobiet [w:] Kobieta i praca. Wiek XIX $i$ XX, red. A. Żarn ow ska, A. Szwarc, t. 6, Warszawa 2000.

Si radzka A., Moda w przedwojennej Polsce, Warszawa 2013.

Szczepański M.S., Modernizacja [w:] Encyklopedia socjologii, t. 2, Warszawa 1999.

Śliw a M., Udział kobiet $w$ wyborach $i$ ich działalność parlamentarna [w:] Równe prawa i nierówne szanse. Kobiety w Polsce międzywojennej, red. A. Żarnow s ka, A. S z w arc, Warszawa 2000.

To mas zew ski J., Landau Z., Polska w Europie i świecie 1918-1939, Warszawa 2005.

Żarnowska A., Kierunki aktywności zawodowej kobiet $w$ Polsce w XX wieku (do 1939 r.) [w:] Kobieta i edukacja na ziemiach polskich $w$ XIX $i$ XX w., red. A. Żarnowska, A. S zw arc, t. 2, cz. 2, Warszawa 1998.

Żarnowska A., Obywatelki II Rzeczypospolitej [w:] Równe prawa i nierówne szanse. Kobiety w Polsce międzywojennej, red. A. Żarnow ska, A. S z w arc, Warszawa 2000.

Żarnows ka A., Si r rakowsk a K., Stare i nowe wzorce i obyczaje rodziny inteligenckiej w Polsce i Europie Środkowo-Wschodniej [w:] Rodzina - prywatność - intymność. Dzieje rodziny polskiej w kontekście europejskim. Sympozjum na XVII Powszechnym Zjeździe Historyków Polskich (Kraków 15-18 września 2004), red. D. Kałwa, A. Walas ze k, A. Żarnow s ka, Warszawa 2006.

Żarnows ki J., Polska 1918-1939. Praca-Technika-Spoleczeństwo, Warszawa 1999.

Żarnowski J., Praca zawodowa kobiet w Polsce międzywojennej [w:] Kobieta i praca. Wiek XIX $i$ XX, red. A. Żarnow ska, A. Szwarc, t. 6, Warszawa 2000. 